\title{
Peningkatan Hasil Belajar Tema Benda di Sekitarku Melalui Metode Pembelajaran Project Based Learning Kelas III SDN Rejosari 03
}

\section{Odditya Setiawan}

SDN Rejosari 03 Kota Semarang

odityasetiawan93@gmail.com

\section{Article History}

received 3/12/2020

revised $17 / 12 / 2020$

accepted 31/12/2020

\begin{abstract}
This research was motivated by the monotonous and boring state of online learning in class III. Teacher Student learning outcomes also show an average below the KKM. Formulation of the problem "How is the management of learning the theme of objects around me through Project Based Leraning for third grade students of SDN Rejosari 03? The purpose of describing the learning management of the theme of objects around me through the Project Based Learning method in class III Classroom action research methods The research sample is class III. The instrument uses observation and tests using the Project Based Learning model, 2 cycles. Based on the research, there was an increase in student learning outcomes both in activities and learning outcomes, the average score of students was as follows: Cycle I $75.42 \%$ with a percentage of $75 \%$, cycle II $93.75 \%$ with a percentage of $100 \%$. It can be concluded that learning the theme of 3 objects around me by using the Project Based Learning learning model, the results of student learning tests experienced an increase in each cycle. The researcher recommends the principal, teachers and related staff in order to develop the quality of learning in the classroom using the PBL learning model.
\end{abstract}

Keywords: learning outcomes, project based learning, classroom research

\begin{abstract}
Abstrak
Penelitian dilatar belakangi oleh keadaan pembelajaran daring dikelas III yang monoton dan membosankan. Hasil belajar siswa juga maih menunjukan rata-rata di bawah KKM. Rumusan masalah "Bagaimanakah pengelolaan pembelajaran tema benda disekitarku melalui Project Based Leraning pada siswa kelas III SDN Rejosari 03?. Tujuan pengelolaan pembelajaran tema benda di sekitarku melalui metode Project Based Learning pada kelas III. Sampel penelitian adalah kelas III. Instrumen observasi dan tes dengan menggunakan model pembelajaran Project Based Learning, 2 siklus. Berdasarkan penelitian, terdapat peningkatan hasil belajar siswa dalam aktivitas maupun hasil belajar, nilai rata-rata siswa sebagai berikut: Siklus I 75,42\% presentase 75\% , siklus II 93,75\% presentase 100\%. Dapat disimpulkan bahwa pembelajaran tema 3 benda di sekitarku menggunakan model pembelajaran Project Based Learning hasil tes belajar siswa mengalami peningkaan tiap siklusnya. Peneliti merekomendasi kepada kepala sekolah, guru beserta jajaran terkait, agar dapat mengembangkan mutu pembelajaran di kelas dengan menggunakan model pembelajaran PBL.
\end{abstract}

Kata kunci: hasil belajar, project based learning, PTK

Social, Humanities, and Education Studies (SHEs): Conference Series https://jurnal.uns.ac.id/shes

p-ISSN 2620-9284

e-ISSN 2620-9292 


\section{PENDAHULUAN}

Pendidikan merupakan hal yang sangat penting bagi negara. Pendidikan sendiri memegang kedudukan yang tinggi dan ditujukan untuk keberlangsungan hidup suatu bangsa dan negara. Dalam Undang-Undang Sistem Pendidikan Nasional Nomor 20 tahun 2003 Bab II Pasal 3, telah dirumuskan secara tegas mengenai dasar, fungsi, dan tujuan pendidikan nasional bahwa: "Pendidikan nasional berfungsi mengembangkan kemampuan dan membentuk watak serta peradaban bangsa yang bermartabat dalam rangka mencerdaskan kehidupan bangsa, bertujuan untuk berkembangnya potensi siswa agar menjadi manusia yang beriman dan bertaqwa kepada Tuhan Yang Maha Esa, berakhlak mulia, sehat, berilmu, cakap, kreatif, mandiri, dan menjadi warga negara yang demokratis serta bertanggungjawab". Undang-Undang Sistem Pendidikan Nasional No. 20 Tahun 2003 Bab II Pasal 2 Ayat 19 menyebutkan bahwa "kurikulum adalah seperangkat rencana dan pengaturan mengenai tujuan, isi, dan bahan pelajaran serta cara yang digunakan sebagai pedoman penyelenggaraan kegiatan pembelajaran untuk mencapai tujuan pendidikan tertentu". Kurikulum senantiasa ditingkatkan mutunya, demikian pula kurikulum di Indonesia.

Menurut Dimyati dan Mudjiono (2013) Definisi hasil belajar merupakan hasil dari suatu interaksi tindak belajar dan tindak mengajar. Dari sisi guru, tindak mengajar diakhiri dengan proses evaluasi hasil belajar. Dari sisi siswa, hasil belajar merupakan berakhirnya penggal dan puncak proses belajar.Selanjutnya menurut Nawawi (2013) Hasil belajar dapat diartikan sebagai tingkat keberhasilan siswa dalam mempelajari materi pelajaran di sekolah yang dinyatakan dalam skor yang diperoleh dari hasil tes mengenal sejumlah materi pelajaran tertentu. Pembelajaran Berbasis Projek Project Based Learning ( $\mathrm{PjBL}$ ) adalah metode pembelajaran yang menggunakan masalah sebagai media. Peserta didik melakukan eksplorasi, penilaian, interpretasi, sintesis, dan informasi untuk menghasilkan berbagai bentuk hasil belajar. Pembelajaran Berbasis Proyek merupakan metode belajar yang menggunakan masalah sebagai langkah awal dalam mengumpulkan dan mengintegrasikan pengetahuan baru berdasarkan pengalamannya dalam beraktifitas secara nyata (Kemdikbud, 2013).

Meningkatkan hasil belajar perlu dilaksanakan dengan serius mengingat masa pandemi Covid 19 seperti sekarang ini belum dapat dipastikan kapan berakhirnya. Dengan mempertimbangan keadaan yang demikian itu,perlu dilakukannya cara-cara yang efektif agar dapat meningkatkan hasil belajar melalui pembelajaran daring atau online. Penggunaan aplikasi-aplikasi pendidikan menjadi salah satu alternatif atau solusi yang digunakan sebagai alat dan media menyampaikan materi pembelajaran selama siswa belajar di rumah.

Maka berdasarkan hal tersebut dilakukanlah pengamatan oleh peneliti pada pelaksanaan pembelajaran benda disekitarku materi perubahan wujud benda, guru kurang menggunakan model pembelajaran yang inovatif, dan kurang menggunakan media pembelajaran yang menarik, pembelajaran masih berpusat pada guru dan kurang melibatkan siswa. Hal tersebut menjadikan siswa selama proses pembelajaran kurang memperhatikan penjelasan guru, dan cenderung merasa bosan sehingga lebih banyak berbicara dengan teman karena baru mengenal zoom meeting saat pembelajaran. Permasalahan-permasalahan tersebut dapat mempengaruhi pembelajaran dan berdampak pada hasil belajar siswa kelas III SDN Rejosari 03. Dari data yang diperolah sebanyak 10 dari 24 siswa mendapatkan nilai di bawah KKM 
yaitu 65. Pembelajaran tema benda disekitarku materi perubahan wujud benda pada kelas III Rejosari 03 mengalami hambatan pada pemahaman konsep. Hambatan yang demikian membuat guru menggunakan metode Project Based Learning (PjBL) sebagai langkah untuk mengatasi hambatan tersebut. Project Based Learning adalah metode pembelajaran yang menggunakan proyek/kegiatan sebagai media. Peserta didik melakukan eksplorasi, penilaian, interpretasi, sintesis, informasi untuk menghasilkan berbagai bentuk hasil belajar.

\section{METODE}

Penelitian ini menggunakan pendekatan Penelitian Tindakan Kelas. PTK merupakan bentuk penelitian tindakan yang diterapkan dalam aktivitas pembelajaran di kelas. Ciri PTK adalah adanya tindakan nyata yang dilakukan sebagai bagian dari kegiatan penelitian dalam memecahkan masalah pembelajaran di kelas (Muhammad Djajadi, S.Pd., M.Pd., Ph.D, 2019: 20). Guru melaksanakan desain pembelajaran project based learning yang telah direncanakan.

Metode pengumpulan data merupakan hal yang harus diperhatikan sebelum melaksanakan penelitian. Karena akan menghasilkan data yang tepat. Pengumpulan data sangat diperlukan untuk mengumpukan data dan informasi hasil dari sebuah penelitian serta diperlukan untuk menguji hipotesis dan menjawab rumusan masalah. Dalam mengukur keberhasilan pengumpulan data maka diperlukan pembuatan instrument. Menurut Purwanto (2016, hlm. 56) "Intrumen adalah alat ukur yang digunakan untuk mengukur dalam rangka pengumpulan data. Teknik analisis data dalam penelitian tindakan kelas tergolong sederhana karena berupa presentasi.

Secara rinci prosedur penelitian tindakan ini dapat dijabarkan dalam 2 siklus. Prosedur pelaksanaan pembelajaran pada siklus II sama dengan siklus I yaitu diawali dari perencanaan, pelaksanaan tindakan, refleksi. Pada siklus II dilakukan oleh peneliti dan guru dengan berdasarkan pada hasil refleksi pada siklus I. Menurut Rochiati Wiriaatmadja (2005: 103), apabila perubahan yang bertujuan meningkatkan kualitas pembelajaran telah tercapai, atau apa yang diteliti telah menunjukkan keberhasilan, siklus dapat diakhiri.

\section{HASIL DAN PEMBAHASAN}

Penelitian ini dilaksanakan di SD Negeri Rejosari 03 Kota Semarang untuk melakukan penelitian terhadap hasil belajar siswa tema sehat itu penting materi persatuan dan kesatuan di lingkungan sekitar kita melalui metode project based learning (PjBL). Setelah peneliti melaksanakan observasi di kelas III SD Negeri Rejosari 03 Kota Semarang, peneliti melakukan berbagai macam persiapan diantaranya adalah menyusun konsep pelaksanaan, membuat jadwal, dan tugas penelitian serta menyusun instrumen yang akan digunakan dalam penelitian. Setelah selesai pelaksanaan penelitian, peneliti menyusun laporan penelitian dengan menyusun laporan hasil penelitian tindakan kelas pada bulan Januari tahun 2020.

Hasil pengamatan aktivitas siswa selama mengikuti pembelajaran tema sehat itu penting materi persatuan dan kesatuan di lingkungan sekitar kita pada kondisi awal dapat dideskripsikan bahwa masih banyak peserta didik yang kurang ketertarikan pada aktivitas belajarnya sehingga kegiatan hasil pembelajaran yang dilakukan kurang maksimal. Dengan kata lain hasil belajar siswa dalam kelas tersebut masih rendah dengan rata-rata nilai 59,58 dan hanya 15 dari 24 siswa yang mencapai KKM atau tuntas dalam belajar. Jika diprosentasekan dalam prosentase ketuntasan belajar hanya $37,5 \%$. Selain itu siswa tampak kurang antusias dalam memperhatikan dan aktif dalam kegiatan belajar dengan baik terbukti masih banyak peserta didik yang kelihatan dalam mengikuti pembelajaran ini. Dapat dibuktikan pada hasil observasi yang menyatakan bahwa rata-rata keaktifan siswa pra siklus hanya mencapai nilai 2,5 . Siswa tampak 
kurang antusias karena seakan-akan tidak mengetahu apa yang seharusnya dikerjakan.

Pembelajaran yang dilakukan oleh guru berlangsung secara daring yang hanya memanfaatkan whatsapp saja. Siswa diminta untuk membaca sendiri materi pelajaran yang ada di buku tema yang disampaikan melalui whatsapp dan tugas-tugas juga diinformasikan melalui whatsapp. Pembelajaran hanya berpusat pada guru yang hanya memberikan tugas melalui whatsapp. Guru juga belum menggunakan media pembelajaran sehingga siswapun kurang bisa memahami materi kewajiban dan hak di sekolah dengan baik. Kurangnya pengawasan dari guru dan orang tua membuat sebagian siswa mengumpulkan tugas terlambat bahkan tidak mengumpulkan.

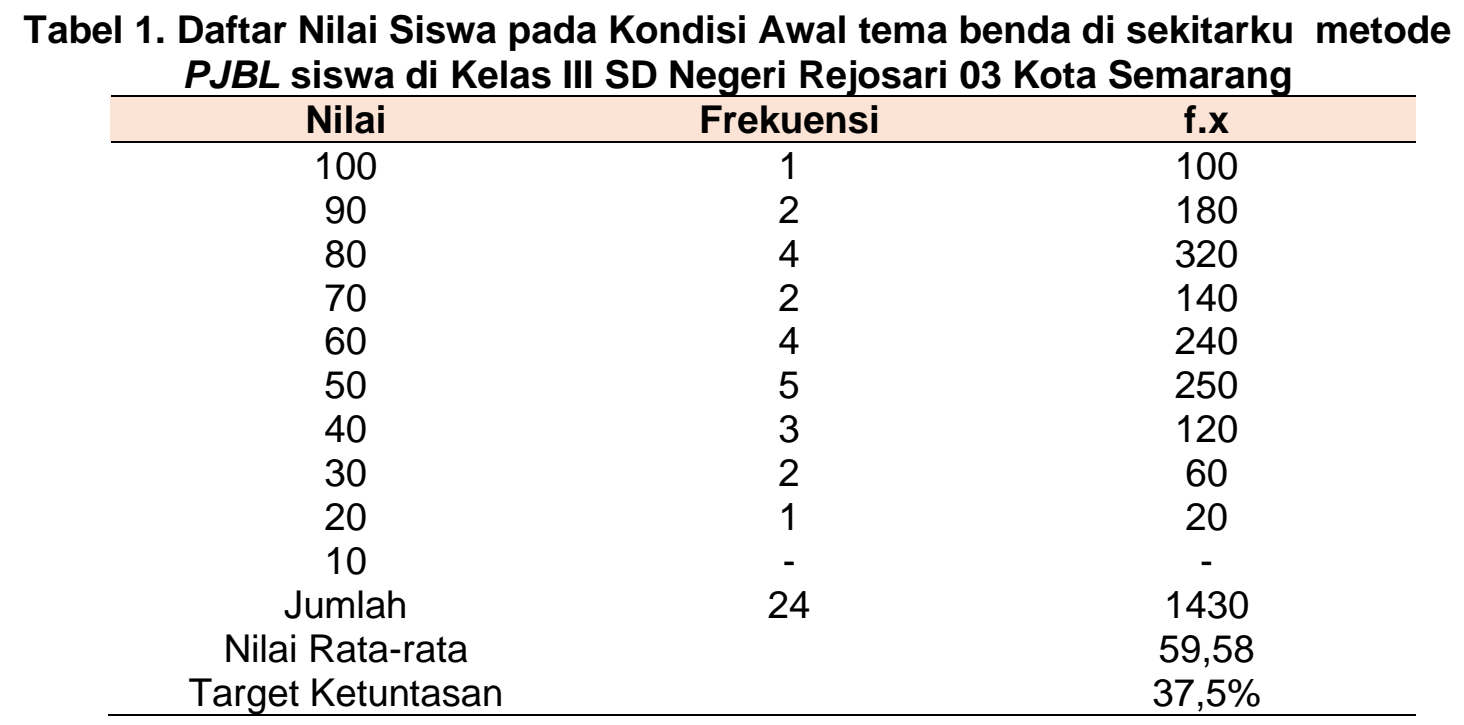

Pembelajaran yang dilakukan oleh guru berlangsung secara daring menggunakan zoom meeting. Siswa diminta untuk bergabung melalui link zoom meeting yang disampaikan melalui whatsapp. Siswa bersemangat mengikuti pembelajaran baru karena keingintahuan yang kuat tentang aplikasi yang sebelumnya belum pernah digunakan. Guru sudah menggunakan media pembelajaran yang menarik berupa powerpoint sehingga siswa mendapatkan penjelasan langsung dari guru sekaligus memperhatikan tayangan yang disajikan guru. Cara ini menunjukkan peningkatan yang cukup signifikan pada hasil belajar siswa,hanya saja pada hafalan belum maksimal. Perlu diadakan peningkatan kegiatan pada siklus II.

Dari sisi guru, kurang memberikan pengarahan kepada siswa untuk segera melakukan kegiatan memberikan tugas dalam mengarahkan siswa untuk menemukan kesulitan dalam belajarnya. Selanjutnya pada siklus 1 guru melakukan tindakan dengan menerapkan model project based learning (PjBL) untuk meningkatkan hasil belajar siswa. Pada siklus 1 ini terdapat perubahan baik dari hasil tes maupun observasi. Dari hasil tes menunjukkan hasil belajar siswa mengalami peningkatan yaitu 17 dari 24 siswa sudah memenuhi KKM atau tuntas dalam belajar. Prosentase ketuntasan pada siklus 1 mencapai $71 \%$. 


\begin{tabular}{|c|c|c|}
\hline Nilai & Frekuensi & f.x \\
\hline 100 & 3 & 300 \\
\hline 90 & 4 & 360 \\
\hline 80 & 5 & 400 \\
\hline 70 & 5 & 350 \\
\hline 60 & 5 & 300 \\
\hline 50 & 2 & 100 \\
\hline 40 & & \\
\hline 30 & & \\
\hline 20 & & \\
\hline 10 & & \\
\hline Jumlah & 24 & 1810 \\
\hline Nilai Rata-rata & & 75,42 \\
\hline Target Ketuntasan & & $70,83 \%$ \\
\hline
\end{tabular}

Pembelajaran yang dilakukan oleh guru berlangsung secara daring menggunakan zoom meeting. Siswa diminta untuk bergabung melalui link zoom meeting yang disampaikan melalui whatsapp. Siswa bersemangat mengikuti pembelajaran karena sudah mulai terbiasa menggunakan aplikasi zoom.Guru sudah menggunakan media pembelajaran yang menarik berupa powerpoint yang disisipi video dari youtube sehingga siswa mendapatkan penjelasan langsung dari guru sekaligus memperhatikan tayangan yang disajikan guru. Cara ini menunjukkan peningkatan yang cukup signifikan pada hasil belajar siswa. Pada hafalan sudah menunjukkan kemajuan yang pesat karena pada dasarnya dengan lagu,siswa lebih mudah menghafal. Masih memerlukan penambahan siklus pembelajaran karena hasilnya belum maksimal meskipun sudah melampaui target atau KKM.

Pada siklus 2 guru merefleksi hasil pada penerapan tindakan dengan menerapkan model project based learning (PjBL) siklus 1 kemudian merencanakan dan melakukan perubahan sehingga meningkatkan hasil belajar siswa. Pada siklus 2 ini terdapat perubahan yang signifikan baik dari hasil tes maupun observasi. Dari hasil tes menunjukkan hasil belajar siswa mengalami peningkatan secara signifikan yaitu semua siswa sudah memenuhi KKM

Tabel 3. Daftar Nilai Siswa pada Siklus II tema benda di sekitarku metode pjbl siswa di Kelas III SD Negeri Rejosari 03 Kota Semarang

\begin{tabular}{ccc}
\hline Nilai & Frekuensi & $\mathbf{f . x}$ \\
\hline 100 & 12 & 1200 \\
90 & 9 & 810 \\
80 & 3 & 240 \\
70 & & \\
60 & & \\
50 & & \\
40 & & \\
30 & & \\
20 & & \\
10 & 24 & 2250 \\
Jumlah & & 93,75 \\
Nilai Rata-rata & & $100 \%$ \\
Target Ketuntasan & &
\end{tabular}


Berdasarkan penelitian, terdapat peningkatan hasil belajar siswa baik dalam aktivitas maupun hasil belajar, nilai rata-rata siswa sebagai berikut: Siklus I 75,42\% dengan presentase $75 \%$, siklus II 93,75\% dengan presentase 100\%. Dapat disimpulkan bahwa pembelajaran tema 3 benda di sekitarku dengan menggunakan model pembelajaran Project Based Learning hasil tes belajar siswa mengalami peningkaan tiap siklusnya. Karena PBL merupakan Model pembelajaran berbasis masalah dapat menyajikan masalah autentik dan bermakna sehingga siswa dapat melakukan penyelidikan dan menemukan sendiri (Wardani 2007:27).

Tabel 4. Uraian pencapaian Hasil belajar siklus 2 tema benda di sekitarku metode PJBL siswa di Kelas III SD Negeri Rejosari 03 Kota Semarang

\begin{tabular}{clc}
\hline No. & \multicolumn{1}{c}{ Uraian Pencapaian Hasil } & Hasil \\
\hline 1 & Uraian Pencapaian Hasil & 24 \\
2 & Jumlah peserta didik mendapatkan nilai $<70$ & 0 \\
3 & Jumlah peserta didik mendapatkan nilai $>70$ & 24 \\
4 & Rerata kemampuan pemahaman terhadap materi Peredaran & 93,75 \\
& Darah & $100 \%$ \\
5 & Persentase Ketuntasan Klasikal & \\
\hline
\end{tabular}

Tabel 5. Rata-rata nilai siswa kelas III tema benda di sekitarku metode pjbl SDN Rejosari 03

\begin{tabular}{lccc}
\hline \multirow{2}{*}{ Aspek } & \multicolumn{3}{c}{ Skor Rata-rata } \\
\cline { 2 - 4 } & Pra & Siklus & Siklus \\
& siklus & $\mathbf{1}$ & $\mathbf{2}$ \\
\hline Nilai tes & 59.58 & 75,42 & 93,75 \\
Nilai observasi & 2,5 & 3,25 & 3,75 \\
\hline
\end{tabular}
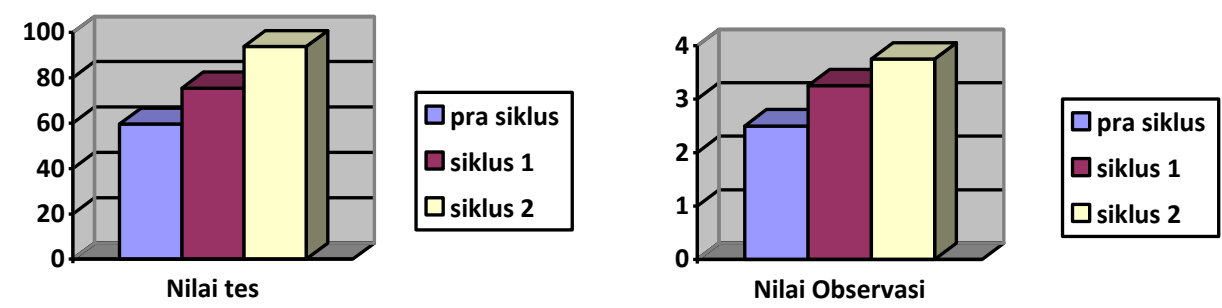

\section{Gambar 1. Hasil belajar siswa kelas III tema benda di sekitarku metode $P J B L$ SDN Rejosari 03}

\section{SIMPULAN}

Berdasrkan hasil penelitian dan pembahasan tentang peningkatan hasil belajar tema Benda di Sekitarku melalui model project based learning pada kelas III SDN Rejosari 03 Tahun Pelajaran 2020-2021, dapat disimpulkan penerapan model pembelajaran project based learning tema Benda di Sekitarku mengalami peningkatan. Hal ini dapat dilihat pada siklus I hasil belajar $70,83 \%$ pada siklus II hasil belajarsiswa mendapatkan skor sebesar 94\% (sangat baik). Dari hasil tersebut dapat dikatakan bahwa hasil penelitian siklus II sudah memenuhi indikator yang sudah ditentukan. 
Model pembelajaran project based learning dapat meningkatkan hasil belajar siswa pada tema Benda di Sekitarku dapat disampaikan saran pada setiap pembelajaran guru sebaiknya menerapkan model dan strategi pembelajaran yang beragam sehingga guru tidak hanya menggunakan metode ceramah, dan penugasan yang menyebabkan hasil belajar siswa kurang. Dengan menggunakan model, strategi ataupun metode yang beragam dapat menciptakan pembelajaran yang efektif dan menyenangkan apalagi pada masa pandemi ditambah dengan variasi bentuk evaluasi,juga diperlukan bagi siswa. kerja sama antara guru dan orang tua sangat penting untuk menunjang keberhasilan pendidikan. Guru dapat memberikan tugas-tugas pembiasaan baik seperti, (1) Ibadah sesuai dengan agama dan kepercayaannya, (2) Cinta tanah air contohnya dengan membeli dan memakai produk dalam negeri dan, (3) Melatih kemandirian contohnya dengan mengerjakan tugas-tugas dirumah secara mandiri.

\section{DAFTAR PUSTAKA}

Permendiknas. 2008. Permen no. 22, 23 dan 24 Tahun 2006. Jakarta : Depdiknas.

Rifa'l, Achmad dan Catharina Tri Anni. 2009. Psikologi Pendidikan. Semarang: Universitas Negeri Semarang Press.

Riyanto, Yatim. 2010. Padigma Baru Pembelajaran: Sebagai Referensi bagi Pendidik dalam Implementasi Pembelajaran yang Efektif dan Berkualitas. Jakarta: Kencana.

Widoyoko, Eko Putro. 2014. Penilaian Hasil Pembelajaran Di Sekolah. Yogyakarta. Pustaka Pelajar.

https://student-activity.binus.ac.id/himpgsd/2017/10/project-basedlearning/\#: :text=Pembelajaran\%20Berbasis\%20Proyek\%20(Project\%20Based, menghasilkan\%20berbagai\%20bentuk\%20hasil\%20belajar

https://www.pelajaran.co.id/2019/15/pengertian-ptk-tujuan-karakteristik-prinsiplangkah-dan-model-penelitian-tindakan-kelas-ptk.html

https://www.zonareferensi.com/pengertian-hasil-belajar/

https://www.seputarpengetahuan.co.id/2016/04/12-pengertian-penelitian-tindakankelas-menurut-para-ahli.htmllnternal (Permendiknas Nomor 47 tahun 2011). Jakarta: Penulis. 